\title{
THE IMPLEMENTATION OF TRADING PLACE STRATEGY TO IMPROVE THE STUDENTS' ABILITY IN READING COMPREHENSION OF REPORT TEXT AT EIGHT GRADE OF MTS S. AL-HUSNA MARINDAL MEDAN ACADEMIC YEAR 2018/2019
}

\author{
Siti Fitri Hasibuan \\ English Applied Linguistics, Post Graduate Program, State University of Medan \\ North Sumatera, Indonesia \\ Corresponding author: fitrihasibuan92@yahoo.com
}

\begin{abstract}
The objective of this research is to find out the improvement of the students' ability in reading the report text by using the trading place strategy. The research was conducted by using Classroom Action Research (Arikunto, 2006). The subject of this study was the nineth grade students in MTs S. AL-Husna, Medan, in academic year 2016/2017. The class consisted of 30 students. The data were taken from the students' score, observation sheet, diary notes and documentation. Based on the reading tests, the students' score kept improvement in every test: from pre-test to post test of cycle I and post test of cycle II. The improvement can also be proved by the result of observation sheet and diary notes. Therefore, It was found that teaching reading the report text by implementing the trading place strategy could improve the students' ability in reading comprehension of the report text.
\end{abstract}

Keyowrds: implementation, ability, report text, trading place strategy

\section{Introduction}

\section{Background of Study}

Reading is one of important skills in learning English. Reading skill is as a far of respective skills that was given in the first priority in the language curriculum. Unfortunately, reading is one of the competence in the curriculum, students still have problem in reading. Whereas, reading is important to help students to gain information such as general knowledge which is needed to insure the continuing personal growth and adapt the change in the world.

Good readers, at a minimum, need to be able to identify main ideas and details; distinguish between facts and opinions; draw inferences; determine author intent, stance, and bias; summarize; synthesize two or more reading passages; and extend textual information to new tasks, such as class projects, oral presentations, and written assignments (Grabe and Stoller 2013). Furthermore, capable readers need a repertoire of reading strategies and the ability to apply them in meaningful 
combinations, at the right times, to achieve their reading goals (Anderson, 2009). Skilled readers also need to be able to read fluently, though at different rates for different reading goals, while maintaining comprehension. For all of this to occur, students' motivation to read needs to be nurtured (Komiyama 2009). Fortunately, explicit instruction that focuses on reading-skills development can greatly help EFL students become more skilled, strategic, motivated, and confident readers. For all these reasons, a comprehensive reading curriculum involves much more than simply assigning a set of pages for students to read and later reviewing students' answers to comprehension questions.

Reading for comprehension is not an easy task. Students must possess interpretation ability to the meaning of the words, expression, and sentences. The main goal of reading instruction must be comprehension, and the students can understand what is on a page.

In teaching reading, most students cannot comprehend the text well. There are some factors why they cannot comprehend text. That students still have problems to get the information from the text and there are some reason why students unable in reading task because some reasons as lack of vocabulary, lack of catch the main idea, difficult to pronounce, and uninterested to read and they are still difficult to get reading comprehension before. Most of teachers just explained and read the text. They couldn't give more understanding about the text. Actually, teaching reading of English learners is exciting for teachers who have the ability to perform it. They must have skills and competence to apply the appropriate teaching strategies, methods, approaches, techniques which can motivate the students to enjoy the printing materials that they distribute. The aim of reading depends on the reader. But mostly the purpose of the reader is to get some information and understanding.

One of solution to improve the students' ability in reading comprehension of the text is using a strategy in teaching process. The teachers have to use a strategy to teach reading comprehension and one of the strategy in cooperative learning is trading place strategy. By trading place strategy, the teacher has a role to guide the students in reading comprehension of the text. The students have more opportunity to interact with the others in understanding the text since they are working in group and it would help them in developing their question and found the answer by reading each section of the text by demonstrating until they had the same understanding of the text each other.

Trading place strategy is about exchange. It hope to the students to know a topic of their friends each other. Trading Place strategy is cooperation strategy to the students, so they can exchange their opinion with the other friends and considere the ideas, solving problem from that issues on the text. It was very useful to solve the problems in reading comprehension due to strategy was suitable for students as a critical reader in reading a text and comparing it with their prior knowledge in order to get deeper understanding the text. 
Proceedings of the $1^{\text {st }}$ Annual International Conference on Language and Literature (AICLL), 18-19 April 2018, Fakultas Sastra, UISU, Medan, Indonesia.

\section{Research Questions of Study}

Based on the background which is given above, so the research problems formulated as follows:

1. How is the students' ability in reading comprehension of report text before using trading place strategy?

2. How is the students' ability in reading comprehension of report text after using trading place strategy?

3. Can the students' ability be increased by using trading place strategy in reading comprehension of report text?

\section{The Aims of Study}

Based on the background in research questions of study above, the aims of study are:

1. To know the students' ability in reading comprehension of report text before using trading place strategy.

2. To know of the students' ability in reading comprehension of report text after using trading place strategy.

3. To know the increase of the students' ability in reading comprehension of report text by using trading place strategy.

\section{Significances of Study}

The result of this research will be expected to be useful for:

1. For the principle in supervising the English teacher to choose the appopriate strategy in teaching-learning English that is suitable for students and subject.

2. For the english teacher have to implement a suitable strategy in reading

3 . For the other reseachers who want to do futher research on the same subject.

\section{Literature Review}

\section{Definiton of Reading}

Reading is one of the language skills that the students have to learn. The goal of teaching reading is make them cope the different text, and prepare them to have access to the text written in English when they continue their study to higher education. It will discuss the objective of reading, strategy in learning reading, finally we discuss how to evaluate reading comprehension.

Reading is a fluent process of readers combining information from a text and their own background knowledge to build meaning. The goal of reading is comprehension. Reading for academic purpose is a multifaceted subject. However, there is one fundamental aspect which can be the starting point for other consideration. When students read, it is for a purpose. The purposes are:

- to understand ideas or theories

- to acquire information (fact or data)

- to discover authors' viewpoints

- to seek evidence for their own point of view or quote all of which may be needed for writing.

Reading comprehension is a complex cognitive process that depends on a number of 
ingredients all working together in a synchronous, even automatic way. Vocabulary clearly plays a critical role in understanding what has been read. Reading comprehension is an essential part of reading instruction and has been examined in many contexts over the years. Typically, teachers have been taught to employ strategies before, during and after reading to get comprehension. The processes in teaching with the notion that students must learn to monitor their understanding and use approaches that help themselves make sense of the text.

Strategy in reading is defined as the ability of the readers to use a wide variety of reading strategies to accomplish a purpose for reading. Good readers know what to do when they encounter difficulties. Fluent reading is defined as the ability to read at an appropriate rate with adequate comprehension.

Teaching reading usually has two aspects. Firstly, it can refer to teaching learners who are learning to read for the very first time. Secondly, teaching reading refers to teaching learners who already had reading skills in their first language.

One of important factor in teaching reading comprehension is students have to be actively involved in the processing and integration of the reading material. Reading material can be divided on several types. In curriculum of Senior High School, the students study about genre or kinds of text and one of genre is report text. We can see how about reading comprehension in report text, but firstly we have to know what is report text.

\section{The students' Ability in Reading}

Ability is defined as the capacity of the individuals to perform various tasks in a specific job. There are three types of ability including Intellectual ability, Physical ability and Job fit ability. Intellectual ability requires the individuals to do the mental activities. Physical ability requires to do tasks like stamina, strength, dexterity, and another similar characteristic. Job fit a capability is linked with employee performance because employee performance is increased when there is a high ability-job fit.

Ability reflects a person's existing capacity ti perform the various tasks needed for a given job and includes both relevant knowledge and skills. Aptitude represents a person's capability of learning something. In other words, aptitude is potential abilities, whereas abilities are the knowledge and skills that an induvidual currently possesses.

\section{Cooperative Learning}

Cooperative learning is homo homini socius that increase to human beings is social beings. It is same with system "mutual assistance". Cooperative learning is a set of instructional strategies used to help learners meet specific learning and interpersonal goals in structured groups. There are some characteristics in cooperative learning;

- Group goals

- Individual accountability

- Equal opportunity for success 
Group goals think about a team sport, such as soccer or volleyball. The teams are unequal ability, but they contribute to the team effort, and winning a game reward the entire team. In learning, it is similarly. Group goals reward students of unequal achievement for working together and helping each other.

Individual accountability, it means that each team member is responsible for mastering the content, and each student is assessed individually. This is an essential idea. Students should understand that everyone is expected to team and that cooperative activities will be followed by and assessment in which they all demonstrate that they understand the content.

Equal opportunity for success, it is for success to all students, regardless of past achievement, has similar chances to be rewarded for their effort. This is accomplished by implementing a system of improvement points, which are bonus points earned for quiz scores that exceed a student's average. This means that students only compare with their past performance and not with each other. Increased effort will result in improvement, which in turn result in points that contribute to the team score.

Cooperative learning is compatible with strategy intruction. A simplified form of cooperation (for example, practicing in pairs and brainstorming study approaches) is one of the strategies emphasized in the met cognitive model of strategies learning. More formal cooperative learning approaches, two stay- two stray, Jigsaw strategy, Trading Place strategy, Teams-Games-Tournaments also can be used to facilitate strategies instruction. Cooperative learning is an excellent way to scaffold instruction because it provides instructional support while increasing student responsibility for learning. Cooperative setting are also useful for identifying students' background knowledge of a strategy or a topic.

\section{Trading Place Strategy}

This strategy is about exchange. It hope to the students to know their friends each other. Trading Place strategy is cooperation strategy to the students, so they can exchange their opinion with the other friends and considere the ideas, solving problem from that issues on the text.

The procedures from this strategies as follow:

1. The teacher gives one or more notes or post it

2. The teacher asks the the students to write on their note one of the problems/issues as follow:

- About their experince

- About ideas and solution creativity from the problems

- About opinion from the issues that common in that time

- About fact from the issues that common in that time

3. The teacher asks the students to paste up on their clothes/pocket and then they around in the room to find out or read their friends' note each other 
4. The teacher asks the students to sit and assosiation about the notes exchange that have read and put on the Trade - Post. They should exchange their notes with the other friends as many as

5. The teacher collect back the students in the class and ask them to give the reason and comment about their friends' note that they have choosen.

\section{Advantages and Disadvantages of Trading Place Strategy}

There are the advantages of Trading Place strategy, as follow:

Advantages

a. Students are active to participant in learning process

b. Efficient to material about text especially to report text

c. To describe the students' character to be more creative, and innovative.

d. Build interpersonal and interactive skill

e. The teacher's effort to develop the students' knowledge to get new information in the world

f. Cooperation in a pair to show the best information

g. Spirit fighting to efficient way in learning process

h. Created bravery, carefulness, and communication accuracy

\section{Disadvantages}

As usual in learning process, if we made new strategy in cooperative learning, they are always difficult to adapt and respond to connect with the material. Even they play and think that the material as game. The strategy can make them confused and askedth the questions, whereas they can discuss with their partner. If they can to answer they will get good score. The other way, if their partner doesn't know about that or material, of course they will get bad score. Therefore, the teacher should random the students well.

\section{Research Method Location of Research}

The research was done at Mts S Al-Husna Marindal Medan. The school is located on Jln Pelajar Medan. Reasons for choosing Mts S Al-Husna Medan as the location of the research are:

1. The writer found the problem of this research in that location

2. This research at this material has never done before.

3. The location of the school is suitable to my ability, limited time, and finance

\section{Research Design}

This research was applied by Classroom Action Research (CAR). According to Arikunto classroom action research is the research to repair the quality in studying practice, so that focus in processing of study in the class. So that a teacher got information well about research was conducted, by doing steps classroom action research, a teacher could fond decision problem that happen in the class. And as researcher Classroom Action Research was conducted with teacher conducted first work, namely teaching in class, stay with student. 
Proceedings of the $1^{\text {st }}$ Annual International Conference on Language and Literature (AICLL), 18-19 April 2018, Fakultas Sastra, UISU, Medan, Indonesia.

\section{Subject of Research}

The subject of this research is grade ninth $\left(\mathrm{IX}^{2}\right)$ students of MTs.S Al-Husna Marindal Medan which consisted of 30 students.

\section{Procedure of Research}

The procedure of data collection for this research was conducted by implementing two cycles. Each cycle consists of three meetings and every meeting include into four steps.

\section{The First Cycle}

Planning, Action, Observation and Reflection

\section{The Second Cycle}

Action research is cyclical. After cycle of planning, action, observation and reflection, the researcher conducted another cycle of action research. That was cycle II. This cycle was done continuously to get satisfying result of the studying.

\section{Instrument of Collecting Data}

The instruments of these research were:

1. Test

In collecting the data, multiple choice test was used. The students were asked to answer the question of multiple choice test, which related to the lesson that have learned multiple choice test was gave in the pre tes, post test cycle 1 and post test cycle 1 and post test cycle 2 . The time which gave to them to finish the test was 30 minutes.

2. Interview

Interview is conversation get information, usually get consisted of two persons or more. Interview was conducted to get information of the students' achievement in reading descriptive text before giving the treatment.

3. Observation

Collecting the data with using participant observation is showing to express the meaning of the haven't is the essentials in qualitative observation. Research observe have a role to observe the object of research such as place of organization, group of people or some activities at school. Observation was used to identify all condition that happen during the teaching and learning process.

4. Documentation

Documentation is anything written that contains information serving as proof. According to Syahrum and Salim in their book, documentation is all of data are collected and interpreted by researcher. And they also were supported by some medias such as: photos, diary notes and video which will be related to research focusing.

\section{Technique of Analyzing Data}

The technique of analyzing the data of this research was applied by using qualitative and quantitative data. The data was used to describe the situation during teaching learning process. Test, interview result and observation sheet was analyzed. The 
quantitative data used to analyze the students' scores. They were collected and analyzed by computing the score of the test.

To know the means of students' scores in each cycle, it was applied the following formula by reasearch:

$$
\begin{aligned}
& \bar{X}=\frac{D X}{N} \\
& \bar{X}=\text { the mean of the students } \\
& \Sigma \mathrm{x}=\text { the total score } \\
& \mathrm{N}=\text { the number of students }
\end{aligned}
$$

Next, to categorize the number of the students who passed the test successfully, it was applied the following formula by researcher:

$$
\begin{aligned}
& \mathrm{P}=\frac{R}{T} \times 100 \% \\
& \text { Where : } \\
& \mathrm{P}=\text { the percentage of students who got point } 75 \\
& \mathrm{R}=\text { the number of students who got point } 75 \text { above } \\
& \mathrm{T}=\text { the total number of students who took the test }
\end{aligned}
$$

To see the change of score that was gotten of students in reading narrative text before using trading place strategy the researcher have to do requirement test first by using pre-test and post-test. The formula was:

$$
\begin{aligned}
& \mathrm{t}=\frac{X_{1}-X_{2}}{s \sqrt{\frac{1}{n_{1}}+\frac{1}{n_{2}}}} \\
& \text { Where: } \\
& \text { X: Mean } \\
& \text { S: Variant } \\
& \mathrm{n} \text { : Subject of the sample }
\end{aligned}
$$

\section{Finding and Discussion}

\section{Finding}

The result was indicated that there was an improvement students' ability in reading report text by trading place strategy. It supported by the fact of the mean from the score in every meeting increased. The mean of the first cycle was $30 \%$. It was very low because the students still had many difficulties in reading report text, and they had challenges to adapt between the new strategy and the old strategy from their real teacher before. From the result above, the first cycle got the mean $63,67 \%$ and the second cycle was $77,33 \%$. It was indicated that the scores and the means in second cycle were better than before (first cycle). The percentage of students who got point up to 65 also grew up. In the pre-test, students who got up 65 there were only 2 of 30 students $(6,67 \%)$. In the post-test of cycle 1 , there were 11 of 30 students who got up $>65(36,67 \%)$. It means that there was improvement about $30 \%$. In the post-test of cycle II, there were 28 of 30 students who got up $>65$ (93,33\%). The improvement was about $56,66 \%$. The total improvement of the students' score pre-test to post test of cycle II was $86,66 \%$. In another word, the students were become better in the first meeting to next meeting by using trading place strategy. 
Proceedings of the $1^{\text {st }}$ Annual International Conference on Language and Literature (AICLL), 18-19 April 2018, Fakultas Sastra, UISU, Medan, Indonesia.

\section{Discussion}

Trading place strategy is an efficient way to learn the course material in a cooperative learning style even less to learn the genre of the text. Reading place strategy more effective, so the purpose of teaching-learning has reached. It made students enjoyable and their ability was higher in learning reading especially in report text. The effect for the students in used team game tournament strategy was easier in teaching -learning process. The English teacher implement many strategies in teaching reading especially Trading place strategy in teaching report text.

In fact, students stated that trading place which made them interested in learning reading. They were more enthusiastic to learn report text seriously and focus. Mean while researcher was given more attention for students in studying through trading place strategy than before conducting it. By analyzing, researcher found that strategy was a flexible strategy than could be used at a variety of levels. It was effective for students in learning about reading especially reading report text. Students also studied in a group and they could be shared about the material with their group and then to the other group. As the result above, that there was an improvement on the students' ability in reading report text through application trading place strategy.

\section{Conclusions}

Based on the result of the research, it be concluded the following points, they are:

1. The usage of Trading Place Strategy can make the students more interested in reading report text. It was supported by the significant of the different result of the pre-test than was lower $(6.67 \%)$ than post-test I of the first cycle $(36,67 \%)$ and posttest II of the second cycle (93.33\%).

2. The implementation of Trading place strategy in teaching report text was effective.

3. Students' ability in reading report text can be improved by applying trading place strategy. The improvement of students' scores from the pre- test of cycle I to the post test of cycle II was about $86,66 \%$. Base on the data analysis, it can be concluded that using $t$ strategy significantly to reading place improved the students' ability in reading report text in Eighth Grade at Mts Swasta Al-Husna Marindal Medan.

\section{References}

Adrienne, L. Herrell \& Jordan, Michael. (2006). 50 Strategies for Improving Vocabulary, Comprehension, and Fluency, United State of America: Pearson Merrill Prentice Hall.

Amber. (2014). Ability, Retrieved June, 2014, from http://www.blurtit.com/q852687.html

Chuz iem. (2013). Report Text. http://www.reporttext.blogspot.com/ Accessed on 04 ${ }^{\text {th }}$ May 2013 at 23:01.

Hamruni. 2009. Strategi dan Model-model Pembelajaran Aktif Menyenangkan. Yogyakarta: Fakultas Tarbiyah UIN Sunan Kalijaga

Nya'bhit, "The Implementation of Number Head Together Strategy in Developing the Students' Achievement to Comprehend Reading Text". Perputakaan IAIN Medan, p.56 